\title{
Pengontrol Alat Penyiram Taman Otomatis Menggunakan SMS Berbasis Mikrokontroller IC Atmega 16
}

\author{
Yurindra \\ Teknik informatika STMIK Atma Luhur \\ Jl.Jend Sudirman Selindung Lama Pangkalpinang \\ Kepulauan Bangka Belitung \\ yurindra@atmaluhur.ac.id
}

\author{
M. Sobri \\ Teknik informatika STMIK Atma Luhur \\ Jl.Jend Sudirman Selindung Lama Pangkalpinang \\ Kepulauan Bangka Belitung \\ $\underline{\text { m.sobri@gmail.com }}$
}

\begin{abstract}
Abstrak-Tujuan pembuatan alat ini adalah untuk mengurangi kerepotan user dari penyiram taman secara manual yang banyak menguras tenaga menjadi penyiram taman secara canggih yang tidak menguras tenaga. Alat ini menggunakan password sebagai pengaman dalam alat ini,sehingga user lain yang mau menjalankan alat ini tidak bisa tanpa mengetahui password tersebut. Selain itu alat ini dapat digunakan secara manual. Hal seperti ini memerlukan suatu pemecahan teknologi yang tepat guna. Pengujian sistem keseluruhan ini merupakan uji coba keadaan-keadaan realitas pada saat digunakan. Pengontrol alat menggunakan sms maupun manual harus menggunakan password yang benar serta menggunakan format sms yang benar dan sudah ditentukan,sehingga user dan alat pengontrol dapat berjalan dengan lancar.User dapat mengendalikan alat tersebut kapan saja dan dari mana saja user berada.
\end{abstract}

Kata Kunci-SMS, Mikrokontroler, ATMEGA 16

\section{PENDAhUluan}

Perkembangan teknologi informasi yang sangat cepat telah memberikan dampak pada globalisasi, terutama pada persaingan bisnis, tuntutan pekerjaan, dan tuntutan gaya hidup menjadi semakin meningkat. Oleh karena itu, untuk mengimbanginya maka manusia menciptakan alat-alat yang dapat bekerja secara otomatis serta memiliki ketelitian tinggi bahkan dapat melampaui ketelitian manusia, agar pekerjaan mereka menjadi lebih mudah.

Saat ini penyiraman taman secara tradisional dirasa kurang efisien karena lamanya dalam penyiraman taman. Tak hanya itu, penyiraman taman secara tradisional membutuhkan banyak tenaga dalam melakukan penyiraman taman. Hal ini menyebabkan pemilik tidak bisa meninggalkan taman dalam waktu yang lama, karena taman dapat kekurangan air. Atas dasar tersebut, alat ini ditujukan untuk membantu pengguna atau pemilik taman dalam menyiram taman tanpa harus disiram secara manual. Alat Penyiram Taman Otomatis ini merupakan salah satu contoh penerapan aplikasi dari IC Mikrokontroler dengan menggunakan perangkat tambahan LCD (Liquid Crystal Display), Alat ini mampu melakukan penyiraman satu kali bahkan lebih dalam sehari selama satu menit. Apabila konsumen ingin melakukan penyiraman lebih dari satu kali, maka dapat mengontrol alat yang diinginkan dengan menggunakan switch yang ada. Alat ini pun mampu bekerja di saat penghuni rumah tidak berada dirumah, sehingga memudahkan pemilik rumah dalam penyiraman taman dan taman pun akan tetap terawat.

Dalam upaya melengkapi data-data atau informasi dalam pengerjaan tugas perancangan sistem ini, maka penulis memperoleh data-data atau informasi yang dibutuhkan tersebut dengan beberapa metode, antara lain studi literatur yang dilakukan dengan mencari dan memahami bahanbahan yang terkait dengan pembuatan pengontrol alat penyiram taman menggunakan sms berbasis mikrokontroller. Kemudian analisa masalah yang dilakukan dengan melakukan pengamatan secara langsung pada tempat - tempat tempat yang membutuhkan mesin pompa air untuk menyiram taman khususnya menggunakan sistem sms yang berada di kota pangkalpinang. Kemudian ada tahapan perancangan system Dari analisa yang dilakukan selanjutnya dibuat rancangan untuk membangun sistem. Rancangan ini meliputi jarak jauh dan secara manual, proses serta alur program.Tahapan yang dilakukan pada perancangan system. Selanjutnya tahapan implementasi yang Berdasarkan implementasi ini sebagai tahapan akhir pembuatan sistem serta hasil uji coba nya,sehingga sistem yang dibuat berjalan dengan lancar dan layak untuk digunakan.

\section{LANDASAN TEORI}

\section{A. Definisi SMS}

SMS (Short Message Service) atau dalam bahasa indonesia layanan pesan singkat. Sebuah sms maksimal terdiri dari 140 bytes, (140 karakter 140 karakter 8-bit, 160 karakter 7-bit atau 70 karakter 16-bit untuk bahasa Jepang, bahasa Mandarin dan bahasa Korea yang memakai Hanzi (Aksara Kanji / Hanja)). 
Namun jika kita ingin menulis lebih dari 140 karakter, kita masi dapat mengirim pesan tetapi si pengguna harus membayar lebih dari sekali.

SMS juga bisa dalam bentuk gambar, suara, dan film. SMS type ini disebut MMS (Multimedia Massaging Service).Kalau dulu manusia dalam mengirim surat harus menggunakan prangko atau merpati pos, tetapi dengan adanya sms ini makan manusia tidak lah perlu menggunakan prangko atau merpati pos tetapi cukup dengan handphone dan pulsa (provider tertentu tergantung pengguna menggunakan provider apa).

\section{B. JET PUMP}

Selama ini, masyarakat awam di negeri ini kebanyakan hanya mengenal beberapa jenis pompa yang biasanya digunakan sebagai penyedia pasokan air bagi kebutuhan rumah tangga atau jenis pompa yang acap kali digunakan sebagai pengisi angin ban kendaraan.

Begitu banyak kegunaan yang ditawarkan oleh pompa. Jenis dari pompa pun semakin beragam sesuai dengan fungsinya. Berikut adalah berbagai pompa-pompa yang banyak beredar di pasaran dan berbagai aspek kehidupan di masyarakat berdasarkan pada prinsip dan cara kerjanya.

- $\quad$ Pompa jenis pertama adalah pompa yang paling sering dipakai untuk kehidupan masyarakat, yakni jenis jet pump. Jet pump sangat baik digunakan sebagai penyedia pasokan air yang sangat penting bagi kebutuhan harian rumah tangga. Jet pump sendiri dapat diklasifikasikan sebagai alat penyedot air yang sangat dalam yang ditunjang oleh motor listrik yang memiliki daya yang besar, baling-baling penyedot air, dan juga penyemprot air yang bertekanan tinggi. Sifat dari jet pump itu sendiri adalah pompa ini dapat mendorong atau mengangkat cairan dari tempat yang sangat dalam. Pompa ini memakai prinsip ejector, dimana dengan adanya perubahan tekanan dari nozzle yang disebabkan adanya aliran media yang dapat berupa cairan atau gas yang digunakan dalam mengankat cairan ke atas. Motor Jet pump sendiri adalah pompa dengan motor dua fasa yang memerlukan adanya kapasitor sebagai penggeser fasa. Pompa ini tidak memiliki bagian yang bergerak dan dibuat dengan konstruksi yang sangat sederhana, yang tentu saja membatasi keefektifan kerja dari jet pump itu sendiri.

- Jenis pompa yang kedua adalah Air lift pump atau juga dapat disebut dengan mammoth pump. Pompa ini memiliki cara kerja yang sangat bergantung kepada campuran antara cairan dan gas. Pompa ini biasanya digunakan dalam sumur yang dalam dan kotor dimana pasir dapat dengan cepat mengikis bagian mekanik. Pompa ini juga terkadang digunakan pada proses pengolahan limbah yang membutuhkan head yang rendah.

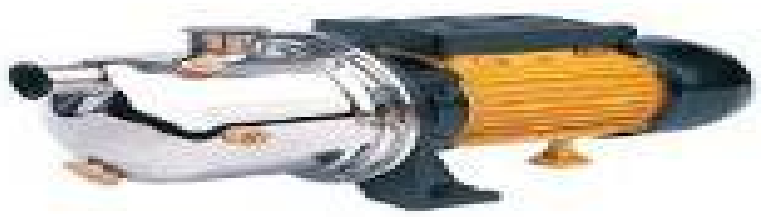

Gambar 1. Jet Pump

\section{Mikrokontroler AVR ATMEGA 16}

AVR merupakan seri mikrokontroler Complementary Metal Oxide Semiconductor (CMOS) 8-bit buatan Atmel berbasis arsitektur RISC (Reduced Instruction Set Computer). Hampir semua instruksi pada program dieksekusi dalam satu siklus clock. AVR mempunyai 32 register general-purpose, timer/counter fleksibel dengan mode compare, interupsi internal dan eksternal, serial UART, programmable Watchdog Timer, power saving mode, ADC dan PWM. AVR pun mempunyai In-System Programmable (ISP) Flash on-chip yang mengijinkan memori program untuk diprogram ulang (read/write) dengan koneksi secara serial yang disebut Serial Peripheral Inteface (SPI).

AVR memilki keunggulan dibandingkan dengan mikrokontroler lain, keunggulan mikrokontroler AVR yaitu memiliki kecepatan dalam mengeksekusi program yang lebih cepat, karena sebagian besar instruksi dieksekusi dalam 1 siklus clock (lebih cepat dibandingkan mikrokontroler keluarga MCS 51 yang memiliki arsitektur Complex Intrukstion Set Compute).

ATMEGA16 mempunyai throughput mendekati 1 Millions Instruction Per Second (MIPS) per $\mathrm{MHz}$, sehingga membuat konsumsi daya menjadi rendah terhadap kecepatan proses eksekusi perintah.

Beberapa keistimewaan dari AVR ATMEGA16 antara lain:

- Mikrokontroler AVR 8 bit yang memilliki kemampuan tinggi dengan konsumsi daya rendah.

- Arsitektur RISC dengan throughput mencapai 16 MIPS pada frekuensi $16 \mathrm{MHz}$.

- Memiliki kapasitas Flash memori 16 Kbyte, EEPROM 512 Byte dan SRAM 1 Kbyte.

- Saluran I/O sebanyak 32 buah, yaitu Port A, Port B, Port C dan Port D.

- CPU yang terdiri dari 32 buah register.

- Unit interupsi dan eksternal.

- Port USART untuk komunikasi serial

- Fitur peripheral

- Tiga buah Timer/Counter dengan kemampuan perbandingan (compare).

- Dua buah Timer/Counter 8 bit dengan Prescaler terpisah dan Mode Compare.

- Satu buah Timer/Counter 16 bit dengan Prescaler terpisah.

- Mode Compare dan Mode Capture. 
- $\quad$ Real Time Counter dengan Oscillator tersendiri Empat kanal

- PWM 8 kanal ADC

- 8 Single-ended Channel dengan keluaran hasil konversi 8 dan 10.

- resolusi (register ADCH dan ADCL)

- 7 Diferrential Channel hanya pada kemasan Thin Quad Flat Pack

- $\quad$ (TQFP)

- Differential Channel dengan Programmable Gain Antarmuka Serial

- Peripheral Interface (SPI) Bus On-chip Analog Comparator

- Non-volatile program memory

\section{1) Timer/Counter}

Mikrokontroler AVR ATMEGA16 memiliki tiga buah Timer/Counter, yaitu : Timer 0 (8 bit), Timer 1 (16 bit) dan Timer 2 (8 bit). Namun, pada sub bab ini hanya akan membahas mengenai Timer/Counter 1 saja. Timer/Counter 1 mempunyai keunggulan dibanding Timer/Counter 0 atau 2, namun cara mengatur Timer 0,1 , 2 sama saja, yaitu pada masing-masing registernya. Timer/Counter 1 dapat menghitung sampai dengan 65536 Timer/Counter 0 atau 2 hanya sampai dengan 256. Selain itu, Timer 1 ini memiliki mode operasi sebanyak 16 mode (Tabel 2.8). Register pada Timer ini dibagi menjadi beberapa register dengan fungsi khusus, yaitu: control register A, control register B dan interrupt mask. Register register pada Timer/Counter 1 yang berfungsi untuk mengatur timer dan mode operasinya.

\section{2) Pemrograman Mikrokontroler ATMEGA 16}

Pengembangan sebuah system menggunakan mikrokontroler AVR buatan ATMEL menggunakan software AVR STUDIO dan CodeVision AVR. AVR STUDIO merupakan software khusus untuk bahasa assembly yang mempunyai fungsi sangat lengkap, yaitu digunakan untuk menulis program, kompilasi, simulasi dan download program ke IC mikrokontroler AVR dapat dilakukan pada CodeVision. CodeVision AVR memilki fasilitas terminal, yaitu untuk melakukan komunikasi serial dengan mikrokontroler yang sudah deprogram. Proeses download program ke IC mikrokontroler AVR dapat menggunakan system download secara In-System Programming (ISP). ISP Flash On-chip mengijinkan memori program untuk diprogram ulang dalam sistem menggunakan hubungan serial SPI.

\section{3) Konfigurasi Pin AVR ATMEGA 16}

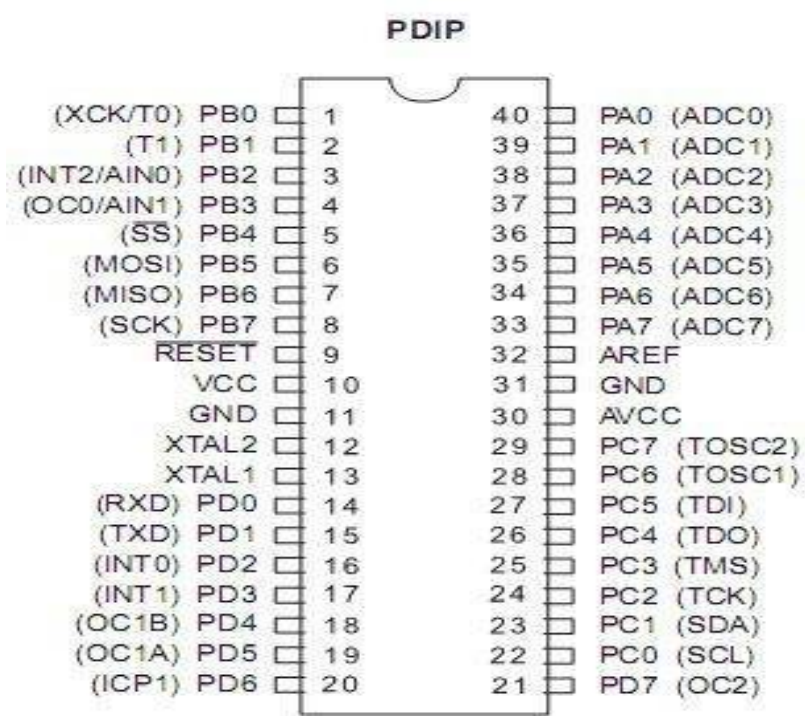

Gambar 2. Konfigurasi Kaki (pin) ATMEGA16

Konfigurasi pin ATMEGA16 dengan kemasan 40 pin Dual In-line Package (DIP) dapat dilihat pada Gambar 2.13. dari gambar diatas dapat dijelaskan fungsi dari masing-masing pin ATMEGA16 sebagai berikut.

- VCC merupakan pin yang brfungsi sebagai masukan catu daya.

- GND merupakan pin Ground Port A.

- Port A (PA0 - PA7) merupakan pin input/output dua arah (full duplex) dan selain itu merupakan pin masukan ADC.

- Port B (PB0 - PB7) merupakan pin input/output dua arah (full duplex) dan selain itu merupakan pin khusus.

- Port C (PC0 - PC7) merupakan pin input/output dua arah (full duplex) dan selain itu merupakan pin khusus.

- Port D (PD0 - PD7) merupakan pin input/output dua arah (full duplex) dan selain itu merupakan pin khusus.

- RESET merupakan pin yang digunakan untuk mereset mikrokontroler

- XTAL1 dan XTAL2, merupakan pin masukan external clock

- AVCC merupakan pin masukan tegangan untuk ADC

- AREF merupakan pin masukan tegangan referensi untuk ADC.

\section{Kapasitor}

Kapasitor adalah suatu komponen elektronika yang dapat menyimpan dan melepaskan muatan listrik atau energi listrik. Kemampuan untuk menyimpan muatan listrik pada kapasitor disebut dengan kapasitansi atau kapasitas. Seperti halnya hambatan, kapasitor dapat dibagi menjadi: 


\section{1) Kapasitor Tetap}

Kapasitor tetap merupakan kapasitor yang mempunyai nilai kapasitas yang tetap.

Simbol Kapasitor Tetap :

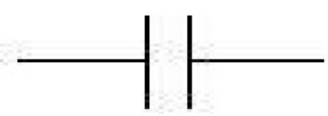

Kapasitor dapat dibedakan dari bahan yang digunakan sebagai lapisan diantara lempeng-lempeng logam yang disebut dielektrikum.Dielektrikum tersebut dapat berupa keramik, mika, mylar, kertas, polyester ataupun film. Pada umumnya kapasitor yanng terbuat dari bahan diatas nilainya kurang dari 1 mikrofarad $3 \mathrm{mF}=1069 \mathrm{nF}=1012 \mathrm{pF}$. Untuk mengetahui besarnya nilai kapasitas atau kapasitansi pada kapasitor dapat dibaca melalui kode angka pada badan kapasitor tersebut yang terdiri dari 3 angka. Angka pertama dan kedua menunjukkan angkaatau nilai, angka ketiga menunjukkan faktor pengali atau jumlah nol, dan satuan yang digunakan ialah pikofarad (pF). Contoh :

Pada badan kapasitor tertulis angka 103 artinya nilai kapasitas dari kapasitor tersebut adalah 10x103 $\mathrm{pF}=10 \times 1000 \mathrm{pF}=10 \mathrm{nF}=0,01$ polaritas (memiliki kutub positif dan kutub negatif) dan biasa melebihi 16 volt.

Simbol elco :
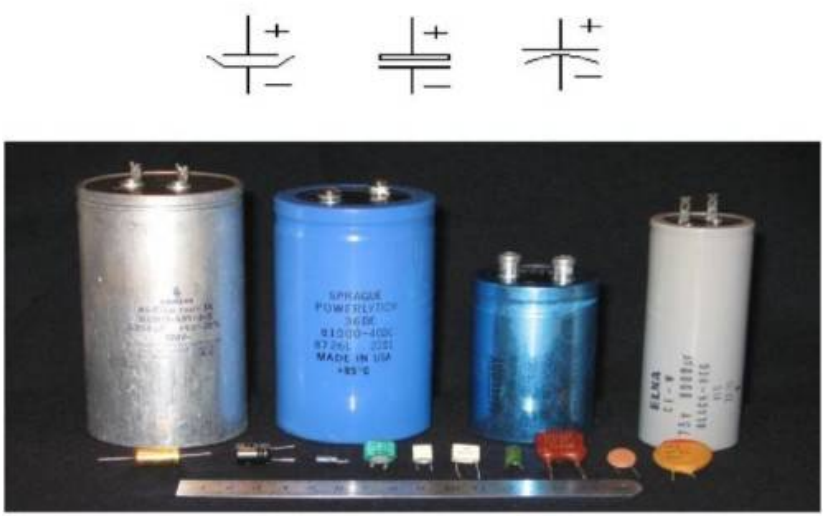

Gambar 3. Kapasitor Tetap

\section{2) Kapasitor Tidak Tetap}

Kapasitor tidak tetap adalah kapasitor yang memiliki nilai kapasitansi atau kapasitas yang dapat diubah-ubah. Kapasitor ini terdiri dari :

a. Kapasitor Trimer

Kapasitor yang nilai kapasitansinya dapat diubah-ubah dengan cara memutar porosnya dengan obeng.
Simbol Trimer

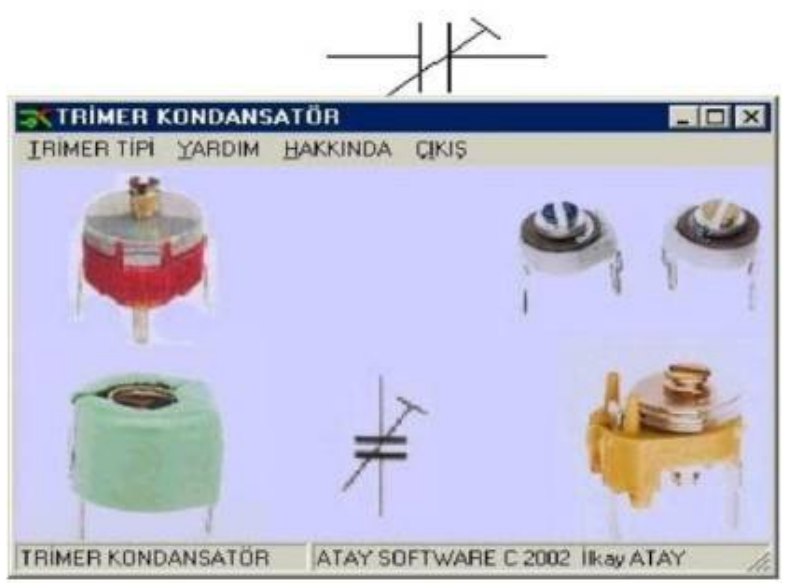

Gambar 4. Simbol Trimer

b. Variabel Capasitor (Varco)

Kapasitor yang nilai kapasitansinya dapat diubahubah dengan

memutar poros yang tersedia. (bentuk menyerupai potensiometer)

Simbol Varco :

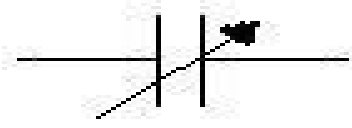

\section{E. Modem Wavecom}

Wavecom Fastrack Modem adalah di Indonesia pada industri bisnis rumah yang cukup dikenal dan bahkan skalafungsi untuk mengirim bulk SMS untuk bertindak sebagai kekuatan pendorong dalam produk elektronik. Modem ini digunakan fungsi yang berbeda dalam masyarakat adalah sebagai berikut:

Fungsi Modem Wavecom:

- Aplikasi SMS broadcast

- SMS aplikasi kuis

- SMS jajak pendapat

- SMS jawaban otomatis

- M2M integrasi

- Aplikasi server pulsa • Telemetri

- Data titik pembayaran

- PPOB

- dll. 


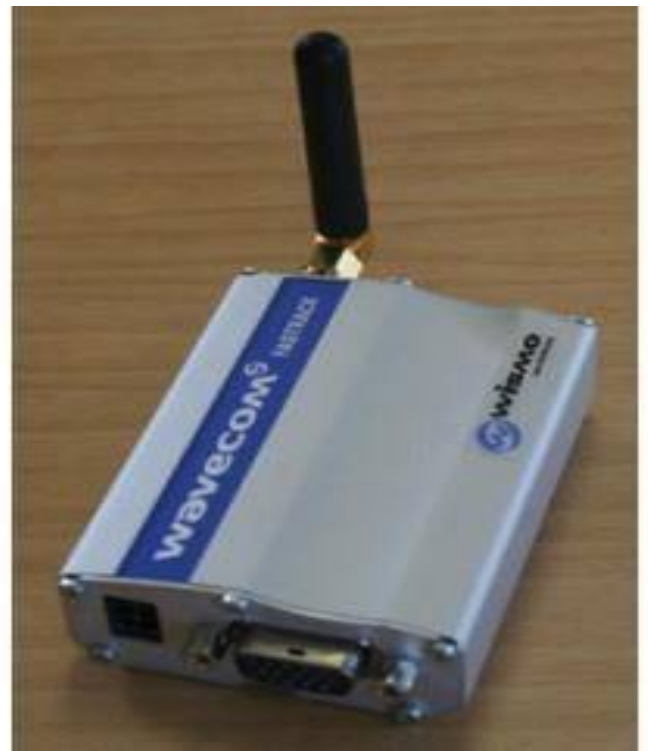

Gambar 5. Modem Wavecom

\section{F. Khazama AVR Programmer}

Khazama programmer adalah sebuah software yang biasa digunakan oleh para pecinta elektronik mikrokontroler untuk mengunduh atau bahasa kerennya mendownload program yang telah dibuat dari misalnya, Bascom AVR, AVR Studio atau masih banyak lagi untuk di transfer pada rangkaian elektronik yang menggunakan mikrokontroler. Sebagai pengetahuan, Khazama Programmer ini sanggup digunakan pada sistem operasi komputer seperti Windows XP, Windows Vista, Dan Windows 7. Data yang di unduh oleh program ini biasanya dari software pembuat program berbentuk File Hex.

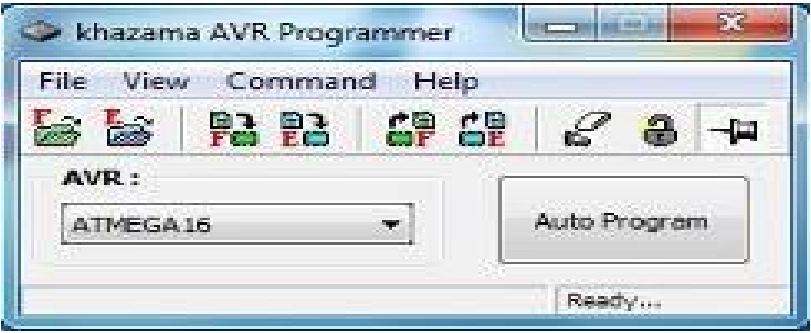

Gambar 6. Khazama AVR Programmer

\section{ANALISA DAN RANCANGAN}

\section{A. Analisa Masalah}

Dengan perkembangan teknologi yang semakin pesat sekarang ini mendorong manusia untuk menciptakan teknologi baru untuk memudahkan orang agar dalam suatu pekerjaan.
Seringkali kita mendengar dan melakukan cara menyiram taman dengan cara manual,maka dari itu memerlukan pemecahan masalah bagaimana cara menyiram taman dengan mudah dan bisa di lakukan dimana saja. Dengan ini terciptalah suatu alat pengontrol penyiram taman otomatis menggunakan sms berbasis mikrokontroler ic ATMEGA 16.

Alat yang tercipta ini sangat membantu memudahkan dalam penyiraman taman baik ditaman dilingkungan rumah maupun taman yang ada dilingkungan perkotaan seperti taman kota. Alat pengontrol penyiram taman ini menggunakan sms yang berbasis mikrokontroler.Dengan demikian pekerjaan dalam penyiram taman ini dapat memudahkan pekerja itu sendiri dan harapan penulis dapat membantu memudahkan dalam pemecahan suatu masalah.

\section{B. Analisa Sistem Berjalan}

Dalam analisa sistem berjalan untuk menghidupkan mesin air dengan cara manual, user langsung bisa menghubungkan jet pump dengan sumber lisrik dengan cara manual tanpa harus menggunakan sebuah sistem dan aplikasi yang moderen.

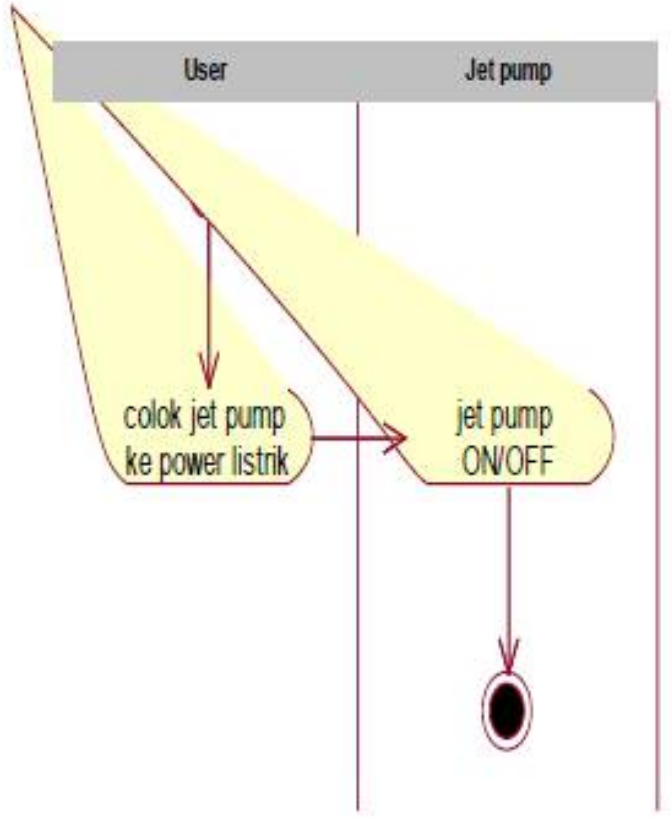

Gambar 7. Gambaran Analisa Sistem Berjalan

\section{Perancangan Sistem}

Dalam tahap perancangan sistem dalam membuat pengontrol alat penyiram taman menggunakan sms kemudian memilih komponen-komponen yang sesuai dengan kebutuhan.Sehingga alat tersebut berjalan dengan lancar dan dapat lebih mudah digunakan oleh user. Dalam perancangan pengontrol alat penyiram taman menggunakan sms ini dengan menggunakan mikrokontroler ATMEGA 16 dan beberapa komponen-komponen yang lain agar alat ini dapat berjalan dengan baik. 


\section{1) Rancangan Proses}

Dalam sistem pengontrol alat penyiram taman menggunakan sms yaitu bisa dikontrol dari mana saja dan kapan saja, cara mengontrolnya menggunakan sms dengan format yang sudah disediakan serta menggunakan password yang sudah diinput sebelumnya sehingga orang lain tidak dapat mengontrol alat itu tanpa mengetahui password tersebut.Adapun seperti gambar dibawah ini:

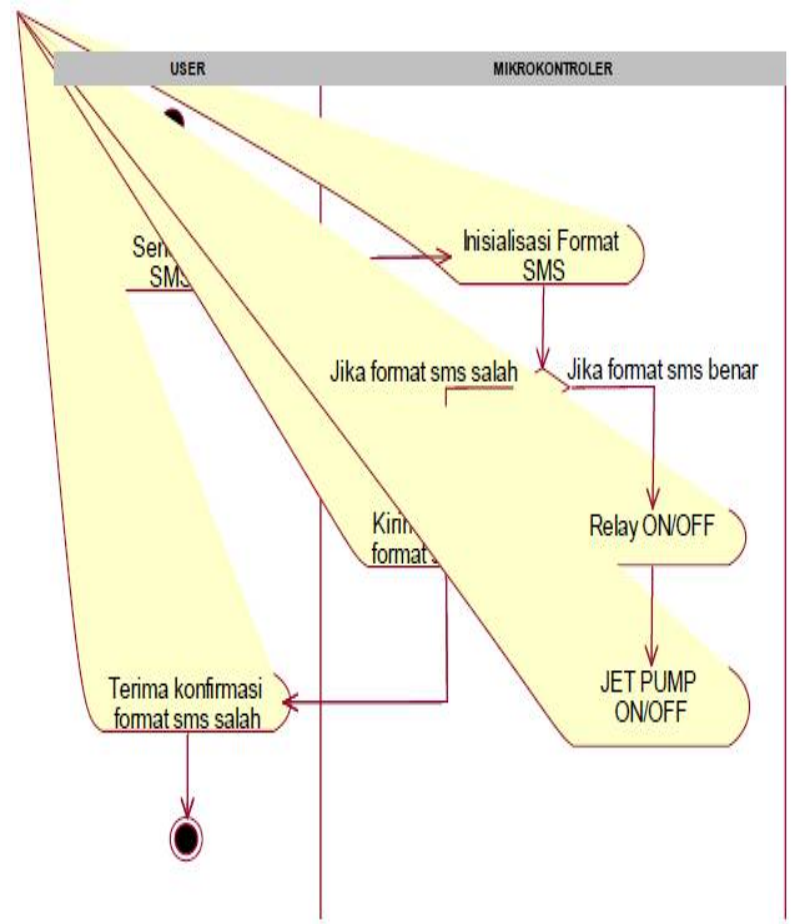

Gambar 8. Activity Diagram Rancangan Proses

\section{2) Perancangan Sistem Kerja}

Perancangan sistem kerja merupakan cara bagaimana sistem berkerja dan komponen alat yang dibutuhkan yang akan dikerjakan,dalam sistem kerja dapat digambarkan dalam diagram blok sebagai acuan keseluruhan sistem.Sebelum ketahap pemograman sistem,dapat diperhatikan bagaimana cara sistem berkerja.Diagram blok dimulai dari Handphone yang digunakan untuk mengirim perintah melalui krim sms ke modem,setelah itu dari modem dilanjutkan lagi ke mikrokontroler ATMEGA 16 untuk memproses yang sudah diperintahkan,setelah perintah sms sudah diproses akan dilanjutkan ke relay agar mesin pompa air dapat menyala dan mesin pompa air dapat menyiram taman dengan otomatis,adapun yang dijelaskan diatas dapat digambarkan dengan diagram blok sehingga dapat dimengerti dengan baik,tampilan diagram blok seperti berikut ini:

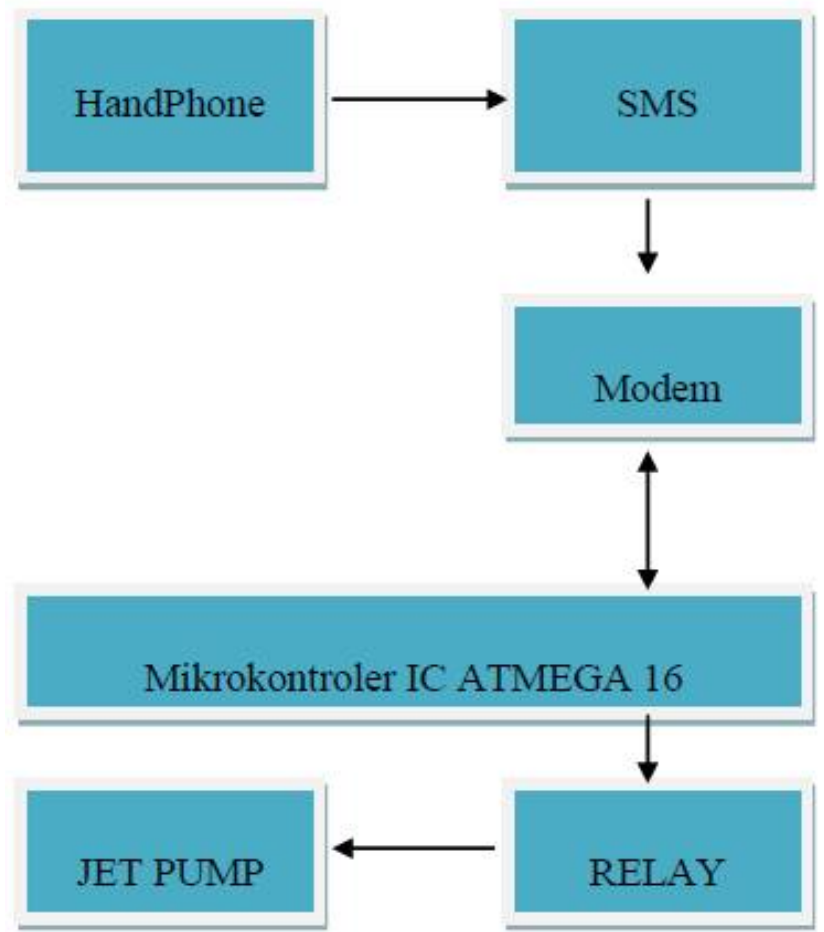

Gambar 9. Diagram Sistem Kendali Jet Pump

Pada diagram blok diatas terlihat bahwa sistem pengontrol alat penyiram taman menggunakan sms terdapat 6 blok yang akan membuat sistem berjalan dengan baik serta memerlukan user untuk memberikan perintah untuk menjalankan sebuah sistem ini,6 blok pendukung dapat diurutkan sebagai berikut:

1. Handphone

2. Modem

3. Mikrokontroler ATMEGA 16

4. Relay

5. Jet Pump

3) Perancangan Perangkat Keras

Perancangan perangkat berfungsi memberikan gambaran perangkat-perangkat yang digunakan untuk membangun system pengontrol alat penyiram taman menggunakan sms berbasis mikrokontroler ini.

\section{4) Rancangan Perangkat Lunak}

Dalam tahapan perancangan perangkat lunak ini dimana tahapan yang ditujukan untuk membuat control yang akan ditanamkan kedalam microchip IC AT MEGA16 sebagai pengontrol semua proses atau otak dari sebuah sistem yang di rancang.

\section{a) Flowchart Menjalankan Secara Manual}

Dimulai dari menekan keypad dengan tombol B,jika tombol B sudah ditekan maka akan muncul perintah masukkan password yang sudah diinput sebelumnya. 
Setelah password sudah dimasukkan muncul perintah untuk menghidupkan relay yang telah terhubung pada jet pump dengan cara menekan tombol bintang(*) maka relay akan terhubung dan jet pump hidup/ON.Untuk mematikan jet pump maka ada perintah lagi untuk menekan tombol bintang(*)maka jet pump OFF.Setelah jet pump OFF ada perintah lagi untuk mengembalikan tampilan LCD seperti semuala,dengan cara menekan tombol D.Adapun penjelasan flowchart seperti gambar dibawah ini:
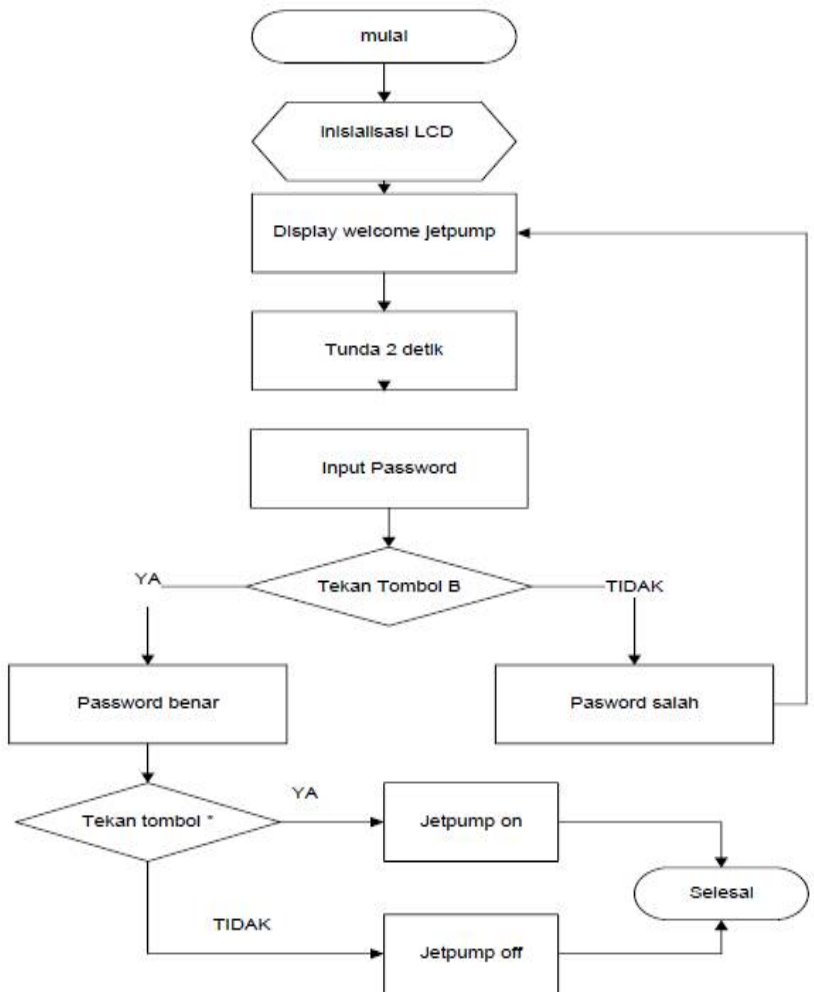

Gambar 9. Flowchart Secara Manual

\section{b) Flowchart Menjalankan Dengan SMS}

Untuk menjalankan alat pengontrol penyiram taman secara otomatis menggunakan sms dipastikan alat sudah menyala dan sudah siap untuk menerima perintah sms.Dimulai user untuk menggunakan handphone dan kirim sms kepada mikrokontroler dengan format yang sudah disediakan sebelumnya dan sudah ada dikodingan.Untuk menjalankan jetpump menggunakan sms dengan format seperti ini : PUMP_ON_PASSWORD, maka jetpump hidup dan apabila format sms yang dikirim salah,Modem yang sudah diproses oleh IC ATMEGA akan mengirim konfirmasi format sms salah.Untuk mematikan jetpump harus mengirim sms lagi ke IC ATMEGA dengan format yang hampir sama dengan format sebelumnya,hanya format sms on menjadi sms off.

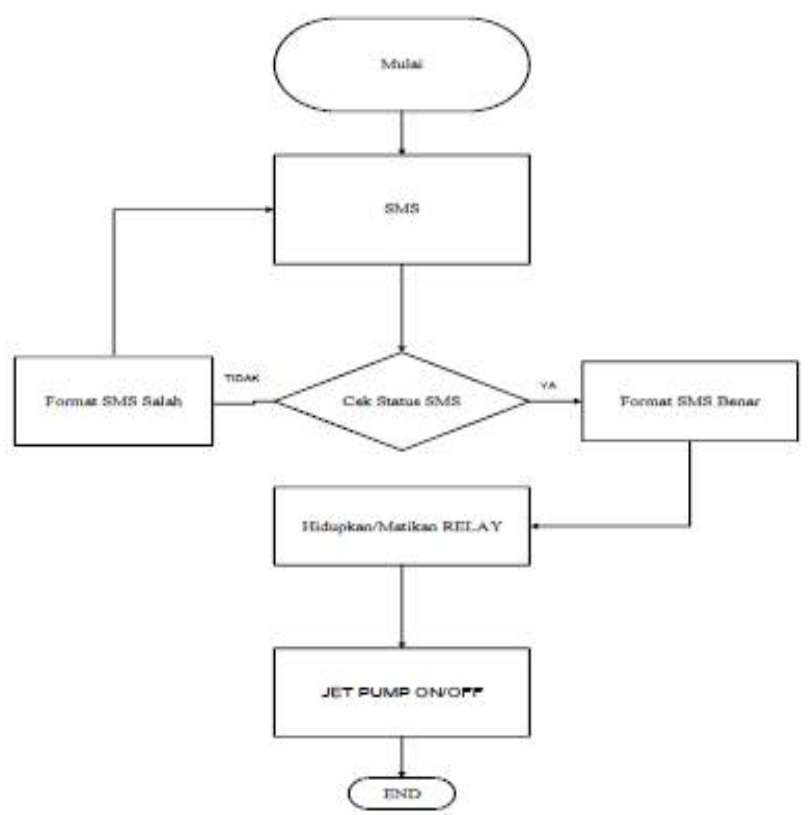

Gambar 10. Flowchart Menjalankan Dengan SMS

\section{Implementasi}

Persiapan bahan dan peralatan pendukung seperti computer untuk penulisan program aplikasi dengan program Code Vision AVR 2.60 Khazama AVR Programer untuk transfer file dan board downloader yang telah include bersama board AT MEGA 16, kabel transfer USB downloader dan rangkaian alat lengkap. Proses penggunaan alat sebagai berikut:

- Tulis instruksi atau kodingan dengan program Code Vision AVR 2.60

- Setelah selesai kita dapat melakukan kompilasi pada program dengan cara pilih menu project lalu pilih Build All atau Ctrl+F9 jika program sudah benar atau tidak terdapat kesalahan.

- Jika sudah tidak terdapat kesalahan dalam penulisan kodingan maka siap di transfer ke dalam IC AT MEGA 16 menggunakan program Khazama AVR Programer.

- Jalankan program Khazama AVR Programer, pilih load flash file to buffer setelah itu cari file yang telah di kompilasi dengan aplikasi Code Vision AVR 2.60 yang berextensi (*.hex) setelah itu pilih jenis dan tipe IC lalu klik auto program. Proses transfer file tersebut akan berjalan secara otomatis dan selesai dalam waktu yang singkat.

- Cabut kabel USB downloader system akan bekerja secara otomatis sesuai dengan perintah untuk system pengontrol alat penyiram taman menggunakan sms.

\section{E. Pengujian Sistem}

Setelah melakukan dan membuat perancangan, maka akan dilakukan pengujian terhadap sistem.Pengujian ini 
dilakukan agar sistem berjalan dengan sempurna. Pengujian dibagi menjadi 3 bagian yaitu pengujian rangkaian relay,pengujian modem,pengujian LCD monitor dan pengujian keseluruhannya

\section{1) Pengujian Rangkaian Relay}

Pengujian rangkaian relay ini untuk mengetahui bagaimana cara kerja relay apabila sudah menerima perintah sms dari user. Relay akan menyala apabila menerima format sms yang benar dari user, Adapun gambar format sms yang benar dibawah ini :

Tabel 1. Pengujian Relay Secara Manual

\begin{tabular}{|c|l|l|l|}
\hline No Keypad & Status Relay & $\begin{array}{l}\text { Hasil yang } \\
\text { diharapkan }\end{array}$ \\
\hline 1 & $\begin{array}{l}\text { Tekan tombol } \\
\text { B pada keypad }\end{array}$ & $\begin{array}{l}\text { Sedang } \\
\text { diproses }\end{array}$ & Relay OFF \\
\hline 2 & Input password & $\begin{array}{l}\text { Sedang } \\
\text { diproses }\end{array}$ & Relay OFF \\
\hline 3 & $\begin{array}{l}\text { Tekan tombol } \\
* \text { pada }\end{array}$ & $\begin{array}{l}\text { Sedang } \\
\text { diproses }\end{array}$ & Relay ON \\
\hline
\end{tabular}

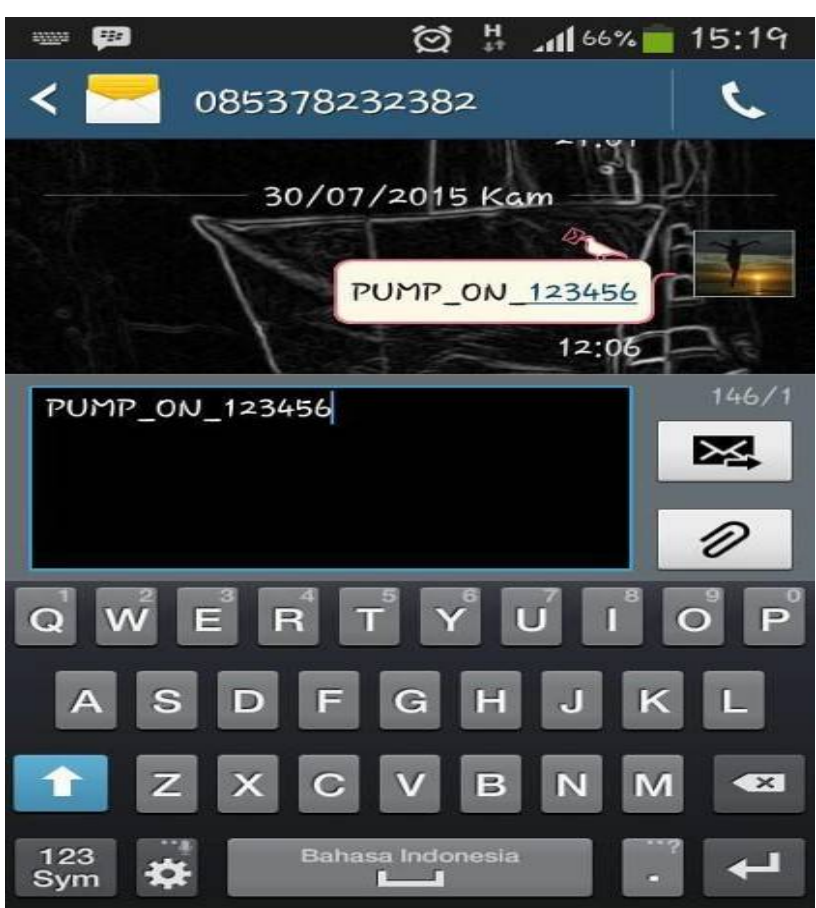

Gambar 11. Pengujian Format sms untuk menghidupkan relay

\section{2) Pengujian Rangkaian Modem}

Pengujian rangkaian modem ini untuk mengetahui sms dari user dan meneruskan perintah dari user ke IC ATMEGA. Apabila format sms benar maka relay akan menyalakan Jet Pump dan apabila format sms salah modem akan mengirim kepada user bahwa format sms salah dan akan memberitahukan format sms yang benar. Adapun contoh gambar dibawah ini:

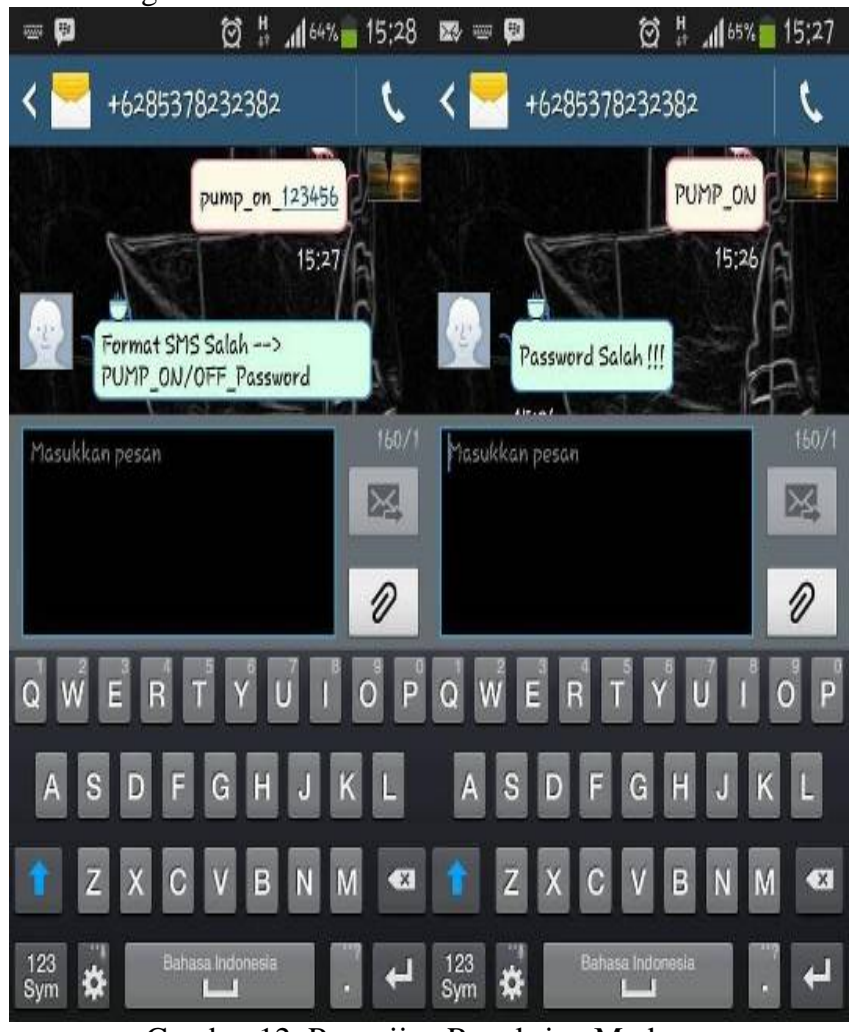

Gambar 12. Pengujian Rangkaian Modem

3) Pengujian Rangkaian LCD

Pengujian lcd monitor bertujuan untuk mengetahui apakah LCD Monitor sesuai perintah program yang diinput. Pengujian LCD Monitor untuk menampilkan tampilan apabila user menghidupkn Jet Pump secara manual menggunakan Keypad dan untuk tampilan memasukan password sebagai kode rahasia untuk menjalankan sistem.

\section{4) Pengujian Keseluruhan Rangkaian}

Setelah dilakukan pengujian komponen rangkaian, maka tahap selanjutnya adalah pengujian keseluruhan rangkaian. Pengujian ini dilakukan untuk mngetahui cara kerja alat apakah berfungsi dengan perintah program yang diinput. Adapun peralatan yang digunakan dalam pengujian ini:

- Rangakaian keseluruhan pengontrol alat penyiram taman otomatis menggunakan sms berbasis mikrokontroler.

- Power supply 12 volt 5 Ampere 
- Handphone

- Sumber air

Tahap pertama yang dilakukan adalah menyambungkan power supply dari sumber listrik ke rangkaian pengontrol alat penyiram taman otomatis, setelah power supply terhubung tekan tombol on/off pada pengontrol alat penyiram taman otomatis dan apabila tombol on/off sudah ditekan,maka di LCD menampilkan perintah tekan tombol A,selanjutnya pengontrol alat penyiram taman otomatis sudah siap untuk menerima perintah dari sms.

\section{F. Hasil Pengujian}

Dari keseluruhan pengujian yang dilakukan maka yang disimpulkan bahwa pengontrol alat penyiram taman otomatis menggunakan sms berbasis mikrokontroler. Alat ini dapat dikendalikan dari jarak jauh maupun dekat. Pengendalian jarak jauh menggunakan sms dan pengendalian jarak dekat menggunakan keypad.pengendalian jarak dekat atau manual menggunakan keypad untuk memasukkan password yang telah di input sebelumnya. Adapun gambar seperti dibawah ini :

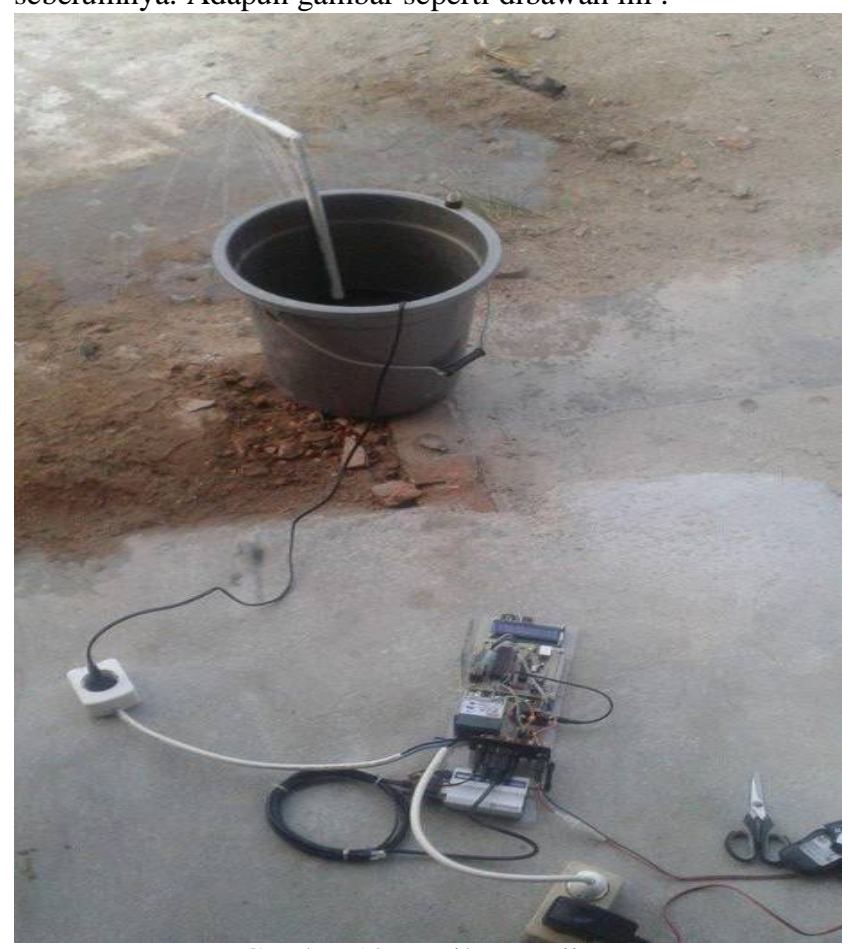

Gambar 13. Hasil Pengujian

\section{PENUTUP}

\section{A. Kesimpulan}

Dari hasil analisis terhadap masalah dan aplikasi yang dikembangkan maka dapat ditarik beberapa kesimpulan, antara lain:
- Dengan adanya pengontrol alat penyiram taman otomatis menggunankan sms berbasis mikrokontroler ini dapat memudahkan pengguna untuk menyiram taman dari jarak jauh.

- Dengan adanya pengontrol alat penyiram taman otomatis menggunakan sms berbasis mikrokontroler ini dapat memudahkan pengguna tanpa banyak menguras tenaga dan dapat dikendalikan kapan saja dan dimana saja.

- Pengontrol alat penyiram taman otomatis menggunakan sms berbasis mikrokotroler ini memerlukan admin dalam menjaga password yang diinput ke sistem,sehingga orang lain tidak dapat mengendalikan alat ini tanpa mengetahui password yang sudah diiput.

\section{B. Saran}

Selain menarik beberapa kesimpulan, juga mengajukan saran-saran yang mungkin bisa dijadikan pertimbangan dalam pengembangan sistem, antara lain:

- Perlu adanya kerjasama antar divisi seperti pihak admin misalnya maintenance security dan User.

- Sumber air dengan pengontrol alat penyiram taman otomatis menggunakan sms berbasis mikrokontroler diharapkan tidak terlalu jauh dan apabila sumber air jauh,maka harus menyediakan tangki air di daerah taman .

\section{DAFTAR PUSTAKA}

[1] Fauzi, I.R. dan Zuda, E.N. "Sistem Peringatan Kebocoran Gas LPG Dan Kebakaran Berbasis SMS Menggunakan Atmega8535". Yogyakarya: 2010.

[2] Febriansyah. Analisis dan Perancangan Keamanan Data Menggunakan Algoritma Kriptografi DES ( data encryption standard ). Palembang: 2012.

[3] Fitrah Rian. Analisis Dan Perancangan Perpustakaan Digital Dan Sistem Otomasi Perpustakaan SMA Negeri 3. Palembang: 2012.

[4] Prabhandita Aditya. Pengembangan Dan Implementasi Media Pembelajaran Trainer Kit Sensor Ultrasonik Pada Mata Diklat Praktik Sensor Dan Transduser Di SMK N 2 Sleman. YOGYAKARTA: 2012.

[5] Saputra, Zainudin 2014. Pengontrolan Lampu Penerangan Menggunakan Mikrokontroler Melalui LAN (Local Area Network) di SMK Negeri 2 Pangkalpinang. Skripsi. STMIK Atma Luhur. Pangkalpinang. 
Jurnal SISFOKOM, Volume 03, Nomor 01, Maret 2014 